\title{
Retail and Distribution in Saranya Agency, Pondicherry
}

\author{
M. Anbarasi, S. Praveen Kumar, G. Madhan
}

\begin{abstract}
An expansion in item assortment and the quantity of item presentations make request supply adjusting procedures work concentrated and inclined to botches. This is particularly the situation when there are numerous levels in the inventory network and the lead-times for material supply and generation are long. The proposed arranging procedure considers that the producer has items at various phases of the item life and uses deals and stock data gathered from merchants and retailers. Preliminaries for the situation organization show that inventory network responsiveness could be improved in item dispatches utilizing the proposed idea. Store network effectiveness in the development stage could likewise be improved. Be that as it may, the helpfulness and adequacy of the created idea relies upon the suspicion that item blend changes can be demonstrated and purpose of-offers and channel sell-through information is accessible routinely and dependably.
\end{abstract}

Key words: planning efficiency, demand visibility, point-of sales.

\section{INTRODUCTION}

Retail originates from the French term retailer, which in terms of tailoring (1365) relates to "cutting off, clipping and dividing." It was first reported as a word in 1433 (French) with the significance of a "purchase in tiny amounts." Its literal meaning for retail was to "cut off, shred, paring". Retail is the final stage of any economic activity. By virtue of this fact, retail occupies an important place in the world economy[1,2].

As per Philip Kotler, Retailing incorporates every one of the exercises engaged with offering merchandise or administrations to the last shoppers for individual, non-business use. A retailer or retail location is any business undertaking whose deal volume comes essentially from retailing. These are the last business substances in a conveyance channel that connections producers to clients. Makers commonly make items and offer them to retailers or wholesalers [3-5].

Retailing broadly involves:

Retailing, therefore, could be understood as the last progress in item appropriation for end-customer use. In essence, any company that provides products to the last buyer plays out the retail ability. It in this manner comprises of all exercises associated with the advertising of commodities and

Revised Manuscript Received on July 22, 2019

M. Anbarasi*, Department of Management Studies, Bharath Institute of Higher Education and Research, Chennai, Tamilnadu, India

S. Praveen Kumar, Department of Management Studies, Bharath Institute of Higher Education and Research, Chennai, Tamilnadu, India

G. Madhan, Department of Management Studies, Bharath Institute of Higher Education and Research, Chennai, Tamilnadu, India enterprises legitimately to the purchasers, for their own, family or family unit use [6,7].

Those with a powerful retail industry were the countries that experienced the biggest financial and social progress. Small family-run chains and regional focused shops dominate the universe over retail business.

Billion-dollar global mixes, such as Wal-Mart, McDonald's, Marks and Spencers, and so on, are continuously taking over a growing amount of company industries in the Western world. The larger distributors established massive supply / dispersion chains, stock management frameworks, funding arrangements and wide-ranging advertising plans that allowed them to deliver improved administrations at aggressive costs by accomplishing economies of scale [8,9].

The individuals measurement is regularly neglected as a key to extend the executives achievement. In any case, human conduct is especially significant in the retail setting, where activities are commonly centered around testing new ideas, expanding coordinated effort, and executing new advances.

This exploration inspects the job of the conduct measurement in retail venture the executives and supports the view that the social measurement is integral to retail extend the executives achievement $[10,11]$.

Advertisers have presented the arrangement of taking steadfast items again from merchants as of late not on the grounds that it's harmed but rather unsold and remunerated with another items. The vast majority of the channel individuals were happy with the present arrangement of FMCG appropriation in the rustic market of Sangli and Kolhapur areas in Maharashtra. The recurrence of inclusion was less for the channels that were situated far away from the feeder town, mulling over cost factor. Shrinkage cost was the greatest risk wholesalers were looking in Sangli and Kolhapur rustic market. The provincial merchants couldn't maintain their organizations without credit to the down line channel [12-14].

\section{A. Retail Concept}

The retail concept is fundamentally a company-wide, customer-oriented approach to the development and implementation of a marketing strategy. It offers instructions that all distributors must follow regardless of their size, channel layout, and selling medium [15].

A retailer is an person, distributor, bureau, organisation, or partnership that is instrumental in reaching a definite purchaser for the 
products, products, or administrations. They are the last company that connects manufacturer to consumers in an appropriation channel. Retailers carry out specific exercises such as predicting the requirements of buyers, generating types of products, acquiring market data, etc.

Retailing includes the way toward selling purchaser products or Services to clients through different channels of dissemination to win a benefit. Retailers fulfill request distinguished through a production network. Probably the most punctual retailers were vagrant merchants. The expression "retailer" is regularly connected where a specialist organization takes care of the little requests of an few discount, corporate or government demographic.

Most contemporary distributors typically create a range of strategic-level choices including the sort of shop, the ideal item range, customer service, support facilities, and the general market positioning of the shop. Once the strategic retail scheme is in location, companies will design the retail combination that will include item, cost, location, promotion, staff and introduction [16-18].

In the digital era, by selling through various channels, including both bricks and mortar and online retailing, an growing amount of distributors are trying to achieve wider economies. The way customers pay for products and services is also evolving with digital techniques. Retail assistance facilities may also include loan facilities, distribution facilities, consultancy facilities, stylist services [19].

Retail stores take place in a variety of kinds and in a variety of environments - from strip malls in personal streets to huge outdoor shopping centres. Shopping boulevards can, as it were, restrict traffic to individuals on foot.

In some instances, a shopping street has a halfway or complete ceiling to render shopping situations progressively comfortable-protecting customers from various kinds of weather circumstances, such as excessive temperatures, winds or rainfall. Non-shop retail types include web retailing and mail requests [20].

QOIE is a retail look and revelation stage for data on famous shopping goals over one's city and neighborhood to help settle on better buy choices. It gives online subtleties of retail outlets for disconnected shopping, inventoried by item classifications. It mixes physical and computerized to make a biological system between the retailers (shopping centers, stores and brands) and buyers over the two universes for a consistent encounter [21].

In spite of the fact that retail is regularly connected with the buy of merchandise, the term might be connected to specialist co-ops that offer to purchasers. Retail specialist organizations incorporate retail banking, the travel industry, protection, private medicinal services, private schooling, private security firms, legitimate firms, distributers, open vehicle and others.

\section{B. Distribution}

1. A good framework for vehicles to take the products to different land areas.

2. A good follow-up structure with the objective of getting the right products in the right quantity at the right moment.

3. A good bundling that requires the vehicle's mileage.
4. Following the places the product can be placed with the ultimate objective of having the most intense opportunity of getting it.

5. It also involves a structure for the swap to recover merchandise.

Dissemination is basic for an industry or administration. The highest quality product, progress and people will come to nothing if the product is not available for sale at the centers where customers can buy [22,23].

Exceptionally, organisations in India's FMCG company distribute their low-esteem, high-volume products to more than 1 million retail stores or offering purposes. The finest FMCG organisations have the largest schemes, consisting of manufacturing installations, inventory focus, dealers or $\mathrm{C} \& \mathrm{~F}$ (carrying and transmitting customers), wholesalers, distributors and buyers. Even immediate promotion these days viewed as a plausible dispersion channel [24-25].

\section{Direct Distribution:}

It is said that a circulation structure is instant when the product or administration leaves the manufacturer and legitimately goes to the client with no officials included. As a rule, this occurs with administrative clearance. For example, both the vehicle wash and the hair stylist use immediate transmission given that the customer receives the administration directly from the manufacturer. This can also occur with organizations selling distinctive goods, such as the adornment manufacturer selling their products directly to the shopper [26].

Indirect Distribution:

Indirect distribution occurs when the distribution channel has middlemen or intermediaries. In the wood instance, the lumber producer, the furniture maker, and the retailer would be the intermediaries. The greater the amount of intermediaries in the pipeline, the greater the final customer's cost is probable to be. This is because of the value adding that occurs at each step within the structure.

The marketing of a brand needs an efficient marketing channel for businesses producing durable goods and other products. Typically, a supply chain has different intermediaries between the supplier and the customer. Distributors, wholesalers and retailers are the most prevalent in the supply chain $[27,28]$.

\section{OBJECTIVES}

PRIMARY OBJECTIVE:

- To study the process of retail and distribution in Saranya Agency, Pondicherry.

\section{SECONDARY OBECTIVE:}

- To observe the process of retail and distribution.

- To find out the difficulties of retail and distribution in Saranya agency.

- To study the development of retail in the company.

\section{RESEARCH DESIGN}

The examination was led in two phases. In stage one, a 
field overview was completed in chosen urban communities of Pondicherry to distinguish key parameters influencing purchaser inclination identified with retail and appropriation. In the following stage, post employment surveys utilizing organized meetings were completed at chosen stores so as to rate the exhibition of particular stores based on distinguished parameters [29].

Research configuration can be exploratory or decisive. On the off chance that you need only investigate the examination issue and you would prefer not to deliver last and convincing confirmations to the exploration issue, your examination configuration would be exploratory. Indisputable research plan, despite what might be expected, intends to give last and convincing responses to the exploration question. Definitive research be additionally separated into two sub-classes [30].

\section{METHOD OF DATA COLLECTION}

For the examination, both important and optional data was collected. Deloitte, Retail Authority of India (RAI), KPMG, Images, Technopark Advisors, Confederation of Indian Industries (CII), and Knight Frank collected auxiliary data associated with the growth of composed retail from retail associated collections [31].

\section{SAMPLING METHODS}

a) Simple Random Sampling (SRS)

b) Stratified Sampling

c) Cluster Sampling

d) Systematic Sampling

e) Multistage Sampling

\section{SAMPLE SIZE:}

The objective populace for stage one of the investigation was the cutting edge retail purchaser of the items. These urban areas were chosen in view of solid nearness of composed retailers in these urban areas. A sum of 150 respondents were talked with utilizing organized poll from every one of chose urban communities of Pondicherry.

Assenters were chosen based on Non-likelihood comfort inspecting. Comfort examining is a non-likelihood inspecting strategy in which respondents are chosen as a result of their helpful availability and closeness to the scientist. This technique appeared to be adequate and suitable considering the exploratory idea of the examination. In any case, endeavors were made to choose purchasers from every cross-segment of populace [32].

During the second phase of study, respondents were met from each examined sorted out retail outlet. Deliberate arbitrary examining procedure was received for the reason. This system was utilized in light of the fact that it is straightforward and results are illustrative of the populace.

\section{TOOLS FOR DATA ANALYSIS}

Linear regression is used to identifying the sources and the process of retail and distribution. Correlation is the statistical tool used to find the process of retail and distribution. The correlation \& linear regression used to analyses the data and the results were presented pictographically using chats [33].

\section{LIMITATIONS}

- This work is limited to the city of Pondicherry, Tamil Nadu due to time constraints.

- This study does not provide a complete picture of these assessments.

- The study was on the effect of retail and distribution.

- Therefore results need not reflect the real life situation.

- The cost of doing business is very high due to heavy overhead expenses.

\section{NEED OF STUDY}

The need of the study on retail and distribution, I have learned about the concept of retailing and distribution.

- Here I have the opportunity to know the views of the public over this concept.

- The purpose of the examination proposal is to demonstrate and legitimize the need to consider the problem of exploration.

- And show the helpful ways in which the examination should be conducted. The circulation part is significant for the reason to sell the item.

These are some of the things I have come to know on this topic "A STUDY ON RETAIL AND DISTRIBUTION IN SARANYA AGENCY”.

\section{SCOPE OF THE STUDY}

- In this examination, I come to think about the ideas of retail and dispersions that happens in "Saranya Agency".

- Many elements add to a retailer's general execution.

- This retail portion is relied upon to precisely mirror the exhibition of composed retail and henceforth the extent of study is restricted.

- This study has further extension to concentrate long haul process with increasingly explicit and more extensive elements.

\section{SELLING THIS TYPE OF PRODUCTS}

TABLE 7: REASON FOR SELLING THIS TYPE OF PRODUCTS: 
Retail and Distribution in Saranya Agency, Pondicherry

\begin{tabular}{|c|c|c|}
\hline CUSTOMERS & RESPONDENTS & $\begin{array}{c}\text { PERCENTAGE } \\
\%\end{array}$ \\
\hline Margin & 15 & $30 \%$ \\
\hline $\begin{array}{c}\text { Promotional } \\
\text { Schemes }\end{array}$ & 12 & $24 \%$ \\
\hline Demand \\
relationship
\end{tabular}

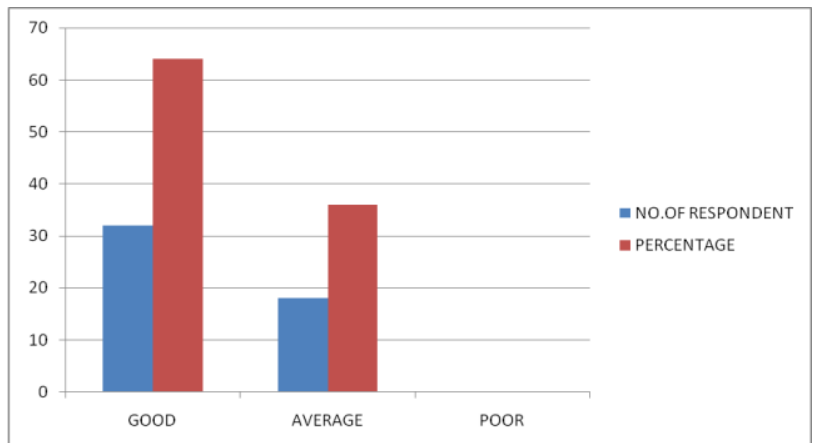

\begin{tabular}{|l|l|l|}
\hline $\begin{array}{l}\text { CUSTOME R } \\
\text { RATING }\end{array}$ & $\begin{array}{l}\text { NO.OF } \\
\text { RE SPONDEN T } \\
\text { Good }\end{array}$ & PE RCENT AGE \\
\hline $\begin{array}{l}\text { average } \\
\text { poor }\end{array}$ & 23 & 44 \\
\hline
\end{tabular}

INTERPRETATION:

The customer rating towards the company is very good and the percentage rating is $64 \%$. And the average rating is $36 \%$ towards the company.

\begin{tabular}{|l|l|l|}
\hline $\begin{array}{l}\text { CUSTOMER } \\
\text { RATINGS }\end{array}$ & $\begin{array}{l}\text { NO.OF } \\
\text { RESPONDENT }\end{array}$ & PERCENTAGE\% \\
\hline GOOD & 32 & $64 \%$ \\
\hline AVERAGE & 18 & $36 \%$ \\
\hline POOR & 0 & 0 \\
\hline
\end{tabular}

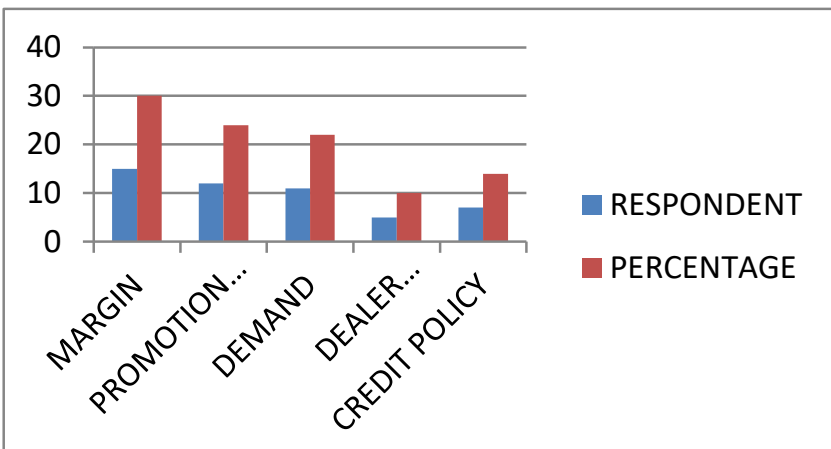

\section{INTERPRETATION:}

The purpose of selling this type of products is because of the margin rate, the margin percentage of the product is $30 \%$. And the demand for this type of product is $22 \%$.

\section{CUSTOMER RATINGS TOWARDS THE COMPANY}

TABLE 8: CUSTOMER RATINGS TOWARDS THE

\section{COMPANY:}

INTERPRETATION:

The credit policies of the company is comfortable to the customer. And the maximum percentage is $28 \%$. And the average percentage is $34 \%$.

TABLE 9: CREDIT POLICIES OF THE COMPANY:
\begin{tabular}{|ll|l|}
\hline Credit policies & $\begin{array}{l}\text { No.of } \\
\text { respondent }\end{array}$ & Percentage\% \\
\hline Good & 29 & $58 \%$ \\
\hline Average & 17 & $34 \%$ \\
Poor & 4 & $8 \%$ \\
\hline
\end{tabular}

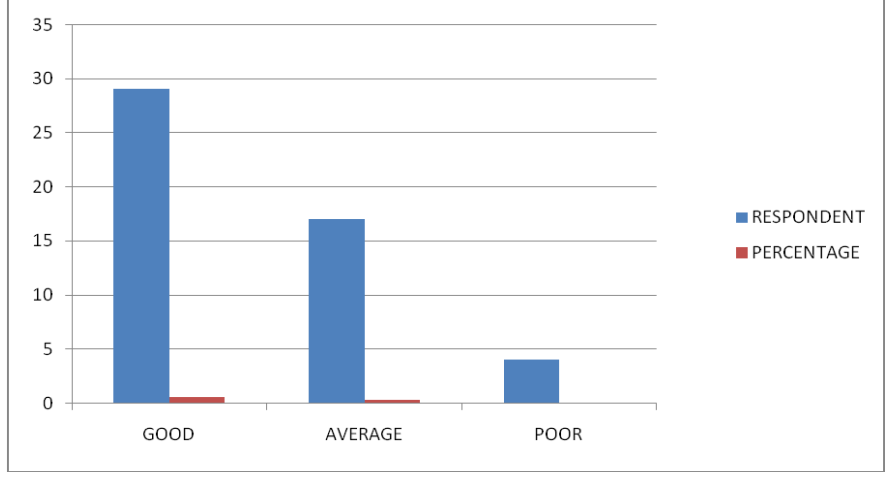




\section{INTERNET USERS}

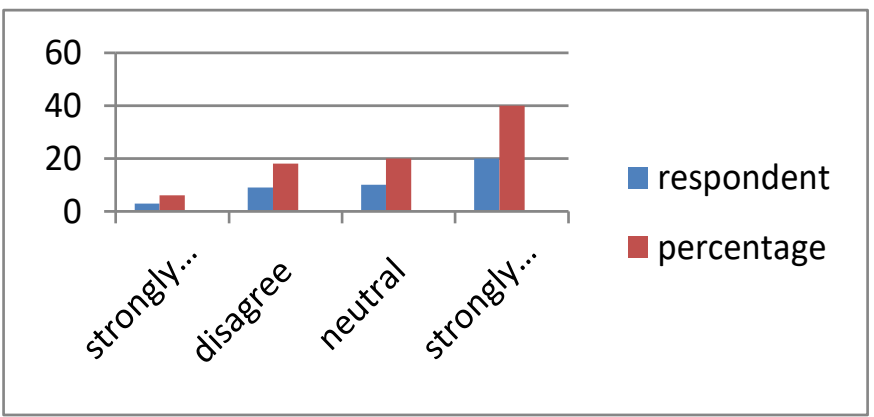

INTERPRETATION:

The customer who uses internet is $40 \%$ agreed by the respondent.

\section{RATING OF BRAND PULL OF SARANYA AGENCY}

TABLE 11: THE RATING OF BRAND PULL OF SARANYA AGENCY

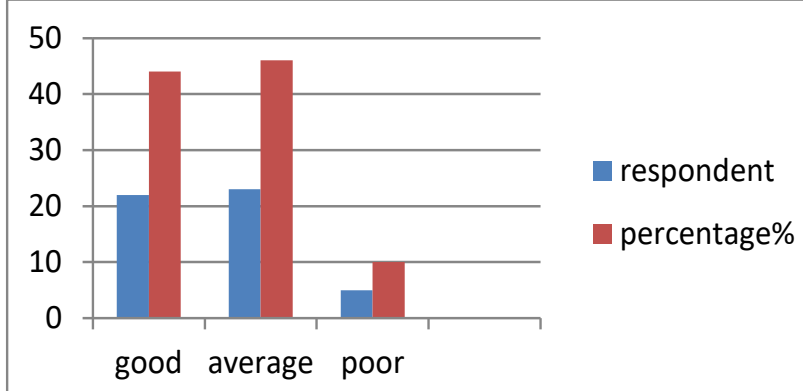

\section{INTERPRETATION:}

The average rating for brand pull is $46 \%$ high.

\section{RESULTS AND DISCUSSION}

- In table $1 \mathrm{I}$ could see that $25 \%$ of the employees are in the age group of 20-25 years old

- In the second table I found out that there are more number of male employees when compared to female employees.

- In table 3, I could see that the customer rating is very good and I found that people like to buy the product.

- Table 4 tells about the customers' satisfaction about the product.

- In the next table it tells about the various schemes and offers provided to the customers.

- In table 6 it tells about the customer satisfaction towards the distributors. It tells about the customers and distributor's relationship.

- In the next chart it is said that the purpose of selling the product.

- In 8th table it tells about the customer rating towards the company. And the rating towards the company is very good.

- The fixed asset turnover ratio of the firm has been increased.

- The next tables tells about the credit policies which gives the major response from the public.

- In table 10 I could see that more number of people are internet users.

- In the next table we can see about the brand pull of Saranya agency which is very good when compared to the other company.

- In the last table It tells us about the customers visiting choice $24 \%$ of the customers visit based on their general interest and few are based on the buying interest and towards the interest over the product.

\section{SUGGESTIONS}

- The level of mindfulness about different deals advancement instruments is exceptionally low aside from on account of Price-Off and Premium plans.

- It is recommended that business advancement plans ought to be adequately sponsored and upheld by print and electronic media promoting. Customers want to get worth included ideas as extra amount of a similar item they purchase as motivating forces.

- Bonus pack plans can be utilized more viably than unconditional presents and compliments.

- Coupon dissemination framework ought to be streamlined, as customers for the most part like to get them through papers and magazines.

- Marketers should stop thoughtless advancement of FMCGs and use advancement plots all the more reasonably and objectively. The advancement mess has made a circumstance where none of the plan is alluring.

- Marketers may utilize Price-off or rebate methodology to accomplish the momentary targets of advancement like brand exchanging, preliminary buy, and amassing in front of different plans. The long haul adequacy of offers advancement is extremely constrained.

- Sales advancement does not prompt continue purchasing or make brand dependability in an attractive way. It might be utilized as a transient measure to diminish stock or avoid rivalry.

- Most of the advancement plans are supported by makers. Retailers, purposely or unwittingly, may not entire heatedly bolster their endeavors. Buyers must guarantee that offers are passed on to them by the retailer or different middle people.

- Consumers may consider the genuine advantages they get and the cost they pay while choosing to benefit an advancement offer since value advancements include more out lay than they ordinarily spend.

\section{CONCLUSION}

In the degree of mindfulness and engaging quality Price-Off offers is a long ways in front of different apparatuses of offers advancement. Cost Off is the most generally utilized deals advancement instrument by shoppers of Fast Moving

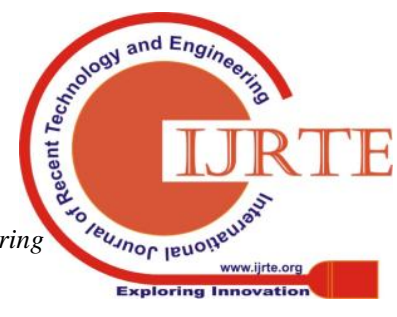


Consumer Goods. Buyers favor Bonus Packs to Free Gifts, Bundled Products and self-exchanging offers. Deals advancement mess has brought about low level use of offers advancement devices by purchasers of FMCGs.

Buyer's repurchase plausibility of the items acquired under deals advancement offers is extremely restricted. Premium plans make/most extreme repurchase occurrences. Shoppers of FMCGs in Kerala are quality cognizant and contemplations of value, offers, and so forth are not extremely solid. Purchasers of FMCGs in Pondicherry are particularly brand steadfast. Plausibility of preliminary buy, brand exchanging, accumulating and utilization speeding up of FMCGs because of offers advancements are not exceptionally reassuring to advertisers Price-Off is the best instrument in rousing purchasers to make preliminary buy, switch brands and store items. Deals advancement does not prompt structure brand faithfulness.

\section{REFERENCES}

1. BharthVajan R., Ramachandran S.,Psychographic dimensions of training,2016,International Journal of Pharmacy and Technology,V-8,I-4,P-23727-23729

2. Balakrishnan P., Bharthvajan R.,A study on human resource planning in hospitals in Chennai City,2014,International Journal of Applied Engineering Research,V-9,I-22,P-7503-7507

3. Priyadarsini P., Bharthvajan R.,Role of emotional intelligence training programme in reducing the stress of the nurses,2014,International Journal of Applied Engineering Research,V-9,I-22,P-7411-7421

4. Kerinab Beenu G., Bharthvajan R.,Empirical analysis on the cosmetic buying behavior of young women in South India,2014,International Journal of Applied Engineering Research,V-9,I-22,P-7361-7366

5. Balakrishnan P., Bharthvajan R.,Whistling in the wind,2014,International Journal of Applied Engineering Research,V-9,I-22,P-7586-7593

6. Krishnan B., Peter M.,Health hazards of Indian Bpo employee-an alarming issue,2014,International Journal of Applied Engineering Research,V-9,I-22,P-7336-7341

7. Kerinab Beenu G.H., Peter M.,Role of insurance in economic development,2014,International Journal of Applied Engineering Research,V-9,I-22,P-7532-7539

8. Balakrishnan P., Peter M., Priyadarsini P.,Efficiency of safety measures for wellbeing of employees in manufacturing industry,2014,International Journal of Applied Engineering Research,V-9,I-22,P-7376-7382

9. Anbarasi M., Praveen Kumar S.,Online sales promotions of herbal products and its effectiveness towards tanisha.com,2019,Indian Journal of Public Health Research and Development,V-10,I-1,P-195-200

10. Anbarasi M., Praveen Kumar S.,Various online marketing and promotions strategies to improve the validation towards the organic products in the pharmaceutical sectors,2019,Indian Journal of Public Health Research and Development,V-10,I-1,P-263-269

11. Loganathan R., Praveen Kumar S.,Grievance handling a key factor for solving issues of employees in an organization,2014,International Journal of Applied Engineering Research,V-9,I-22,P-7483-7491

12. Loganathan R., Praveen Kumar S.,Study on preference of private label brands in super and Hypermarkets,2014,International Journal of Applied Engineering Research,V-9,I-22,P-7327-7335

13. Smitha M., Praveen Kumar S.,Understanding stress and its managementamong the nurses in Chennai city,2014,International Journal of Applied Engineering Research,V-9,I-22,P-7560-7565

14. Kerinab Beenu G.H., Praveen Kumar S.,A study on the investment behavior of Chennai investors in mutual fund schemes,2014,International Journal of Applied Engineering Research,V-9,I-22,P-7520-7525

15. Loganathan R., Praveen Kumar S.,Retention strategies key for organizational productivity,2014,International Journal of Applied Engineering Research,V-9,I-22,P-7443-7447

16. Pavithra J., Ganesan M., Brindha G.,State wise analysis of microfinance sector in India,2016,International Journal of Pharmacy and Technology,V-8,I-4,P-23417-23432
17. Pavithra J., Ganesan M.,A comparative study on microfinance in India and abroad,2016,International Journal of Applied Business and Economic Research,V-14,I-8,P-5471-5476

18. Pavithra J., Ganesan M.,A study on awareness and impact of micro-financial schemes,2016,International Journal of Applied Business and Economic Research,V-14,I-8,P-5449-5460

19. Senthilmurugan P., Pavithra J.,Consumer preference towards organised retailing with reference to Big Bazaar,2014,International Journal of Applied Engineering Research,V-9,I-22,P-7469-7475

20. Senthilmurugan P., Pavithra J.,Implication of social media marketing in growing healthcare industry,2014,International Journal of Applied Engineering Research,V-9,I-22,P-7448-7456

21. Loganathan R., Pavithra J.,Consumer perception towards private label brand over other brands in super markets and hypermarkets,2014,International Journal of Applied Engineering Research,V-9,I-22,P-7355-7360

22. Kerinab Beenu G., Pavithra J.,Tradeâ€"off between liquidity and profitability in logistics industry,2014,International Journal of Applied Engineering Research,V-9,I-22,P-7398-7401

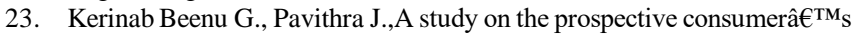
perception towards utility cars in Chennai city,2014,International Journal of Applied Engineering Research,V-9,I-22,P-7526-7531

24. Pavithra J., Dilli Babu P., Ambuli T.V.,A study on budgetary control at Maruti Service Masters, Chennai,2014,International Journal of Applied Business and Economic Research,V-12,I-2,P-151-161

25. Pavithra J., Dilli Babu P., Ambuli T.V.,A study on customer satisfaction of retro Garments Pvt Ltd, Chennai,2014,International Journal of Applied Business and Economic Research,V-12,I-2,P-381-391

26. Kerinab Beenu G.H., Pavithra J., Senthilmurugan P.,A study on the influence of promotional activities for TATA ARIA among consumers in Chennai,2014,International Journal of Applied Engineering Research,V-9,I-22,P-7572-7578

27. Vijayaragavan S.P.,An investigative expert that's general FBG sensors,International Journal of Mechanical Engineering and Technology,V-8,I-8,PP-1500-1505,Y-2017

28. Vijayaragavan S.P.,Equalization routing protocol for Wi-Fi sensor strategy,International Journal of Mechanical Engineering and Technology,V-8,I-8,PP-1662-1666,Y-2017

29. Karthik B., Kiran Kumar T.V.U., Vijayaragavan P., Bharath Kumaran E.,Design of a digital PLL using 0.35 $\hat{\mathrm{I}}^{1} / \mathrm{m}$ CMOS technology,Middle East Journal of Scientific Research,V-18,I-12,PP-1803-1806,Y-2013

30. Kanniga E., Selvaramarathnam K., Sundararajan M.,Kandigital bike operating system,Middle - East Journal of Scientific Research,V

31. Jasmin M., Vigneshwaran T., Beulah Hemalatha S.,Design of power aware on chip embedded memory based FSM encoding in FPGA,International Journal of Applied Engineering Research,V-10,I-2,PP-4487-4496,Y-2015

32. Jasmin M.,Optimization techniques for low power VLSI circuits,Middle East Journal of Scientific Research,V-20,I-9,PP-1082-1087,Y-2014

33. Jasmin M., Vigneswaran T.,Fuzzy controller for error control of on - Chip communication,2017 International Conference on Algorithms, Methodology, Models and Applications in Emerging Technologies, ICAMMAET 2017,V-2017-January,I-,PP-1-5,Y-2017

\section{AUTHORS PROFILE}

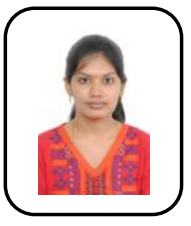

M. Anbarasi, Student, Department of Management Studies, Bharath Institute of Higher Education and Research, Chennai, India

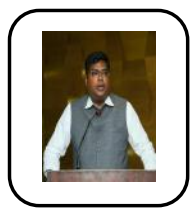

S. Praveen Kumar, Associate Professor, Department of Management Studies, Bharath Institute of Higher Education and Research, Chennai, India

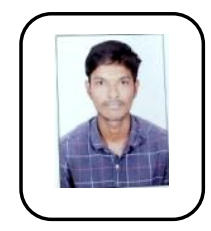

G. Madhan, Student, Department of Management Studies, Bharath Institute of Higher Education and Research, Chennai, India 